\title{
7. VELOCITY-POROSITY RELATIONSHIPS OF BASALTS FROM THE EAST PACIFIC RISE ${ }^{1}$
}

\author{
Joel E. Johnston, ${ }^{2}$ Gerard J. Fryer, ${ }^{3}$ and Nikolas I. Christensen ${ }^{2}$
}

\begin{abstract}
Seismic experiments over young crust consistently measure velocities in the uppermost extrusives substantially lower than that of massive basalt. The differences arise from the high porosity of the rock, but the scale of that porosity (is the porosity from large fractures or from microcracks?) is unknown. To relate porosity at the hand sample scale and smaller to that at the seismic scale we performed physical-properties measurements on 17 basalts from the East Pacific Rise (EPR) near $9^{\circ} 30^{\prime} \mathrm{N}$, two from Site 864 in the axial summit caldera and the remainder from dredge hauls, for comparison with detailed seismic refraction work that had been performed at Site 864 during site surveys.

The elastic properties of a rock are profoundly affected by the shape of any pore space, so knowledge of the distribution of porosity over pore aspect ratio is essential to understanding the seismic velocities of the rock. We measured velocity as a function of confining pressure up to $600 \mathrm{MPa}$ and from the dependence of velocity on pressure inferred a distribution of porosity over different crack shapes. We qualitatively verified our estimates of crack shape from scanning electron microscope images of the samples.

The Site 864 samples have the highest porosity (3\%), the lowest seismic velocities $\left(V_{p}=5.4 \mathrm{~km} / \mathrm{s}\right.$ at $50 \mathrm{MPa}$, water saturated), and the highest population of thin cracks. They contrast markedly with the dredge samples from the EPR axis, which have low porosity $(<2 \%)$ and high velocities $(6.0 \mathrm{~km} / \mathrm{s})$. Off-axis dredge samples have intermediate properties. The difference in properties seems unrelated to flow type: the dredge samples from the axis are from massive, sheet, and lobate flows; the two Site 864 samples are probably from a massive flow; and the off-axis dredge samples are from pillows. Instead, the key property seems to be crystal size. The Site 864 samples and the slower of the off-axis samples are all fine grained, the remainder of the off-axis samples and all the dredge rocks from the axis are microcrystalline to cryptocrystalline. In every sample, damage from microcracks is most pronounced in the largest crystals. The pattern of microcracks appears consistent with release of confining pressure from low-permeability rocks with high pore pressure; the rocks have been damaged as a consequence of being brought up from the bottom. This problem is probably common to all zero-age basalts.

Our measurements in the laboratory must include the effects of any microcracks introduced by the collection process; at the seafloor the concentration of microcracks may be substantially less. Although there will be some variation with flow type, all very young basalts probably have a compressional velocity similar to our uncracked samples, about $6 \mathrm{~km} / \mathrm{s}$, in situ. Because seismic measurements of velocity of the uppermost zero-age crust are typically about $2.2 \mathrm{~km} / \mathrm{s}$, it is clear that fractures, pillow margins, and other features much larger than the scale represented by laboratory samples are of primary importance in controlling the seismic properties of the ocean bottom.
\end{abstract}

\section{INTRODUCTION}

Seismic measurements at oceanic spreading centers yield values of $2.5 \mathrm{~km} / \mathrm{s}$ or less for the compressional wave velocity of the uppermost extrusives (Purdy, 1987; Harding et al., 1989; Vera et al., 1990, Christeson et al., 1992). The extrusives are basalt, yet massive, nonvesicular basalt has a compressional-wave velocity of about $7 \mathrm{~km} / \mathrm{s}$ (Wilkens et al., 1988). The reason for the large difference, of course, is that the extrusives are vesicular, fractured and brecciated, and formed into flow units with selvages, interpillow voids, and other porosity (Schreiber and Fox, 1976; Spudich and Orcutt, 1980; Wilkens et al., 1991). Porosity at all scales influences seismic velocity, so from seismic measurements alone we can learn nothing about scale; vesicles and interpillow voids are indistinguishable to a seismic wave with a wavelength many times greater than the size of the void space.

Not only does porosity affect the seismic structure at spreading centers, it also influences the crust's evolution. There is one, and only

'Batiza, R., Storms, M.A., and Allan, J.F. (Eds.), 1995. Proc. ODP, Sci. Results, 142: College Station, TX (Ocean Drilling Program).

${ }^{2}$ Department of Earth and Atmospheric Sciences, Purdue University, West Lafayette, IN 47907, U.S.A.

${ }^{3}$ School of Ocean and Earth Science and Technology, University of Hawaii at Manoa, Honolulu, HI 96822, U.S.A. one, clear age dependence apparent in the seismic structure of oceanic crust: the increase in mean velocity of Layer $2 \mathrm{~A}$, the uppermost layer of extrusives (Houtz and Ewing, 1976; Purdy and Ewing, 1986). It is now widely recognized that this age dependence is a consequence of pore space modification by hydrothermal deposition and alteration (Wilkens et al., 1991; Jacobson, 1992). This progressive deposition in the pore space changes pore shape, which has a profound effect on seismic velocities and yields a velocity increase with only a minor reduction in porosity. Although rock physics theories can explain the velocity increase (Wilkens et al., 1991), the details of the crustal evolution processes remain unknown. In particular, because seismic waves contain no information about the size of the void space it is not known for certain at what scale the processes act.

Laboratory measurements on hand samples provide information only about the small-scale porosity (microcracks, vesicles), but when combined with the seismic information provide useful insight into how the pore space is distributed over different scales. In this study, we have measured in the laboratory the physical properties of Layer $2 \mathrm{~A}$ basalts from the East Pacific Rise (EPR) with an emphasis on constraining the porosity structure of the samples through ultrasonic measurements of shear- and compressional-wave velocities. The basalts studied were collected during Ocean Drilling Program Leg 142 and a separate dredging expedition and come from both axis and off-axis sites. Our intent was to study the microscopic porosity structure of Layer $2 \mathrm{~A}$ and to establish the zero-age endmember for crustal 


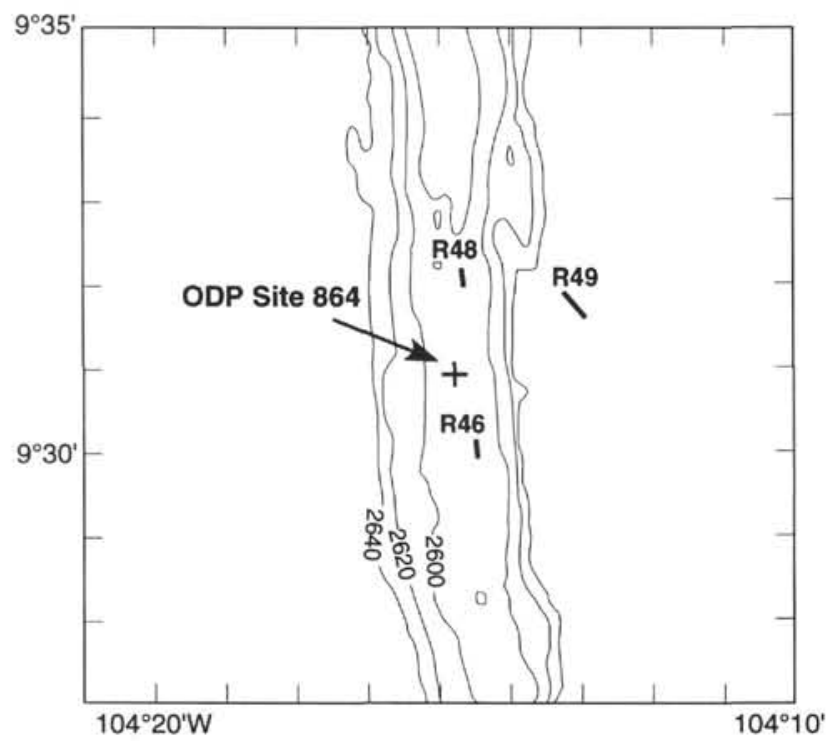

Figure 1. SeaBeam base map showing Site 864 and dredge locations (modified from Batiza and Niu, 1992).

evolution studies. Our accomplishments have been somewhat different. Principal among them has been an understanding of the practical difficulties in measuring the properties of very young seafloor basalts.

\section{EXPERIMENTAL PROCEDURE}

Two minicore samples were obtained during Leg 142 for physical-property analysis, one from Hole $864 \mathrm{~A}$ and the other from Hole $864 \mathrm{~B}$. The Hole 864B sample (142-864B-2W-1, Piece 2) is from Unit 1, an aphyric basalt unit of massive flows and sheet or lobate flows (Shipboard Scientific Party, 1993). Drilling difficulties make a depth determination difficult, but the rock is probably from $0-3 \mathrm{~m}$ below seafloor (mbsf). The Hole 864A sample (142-864A$5 Z-1$, Piece 3 ) is from the underlying Unit 2, a fine-grained aphyric basalt unit, probably of massive flows (Shipboard Scientific Party, 1993). The Hole 864A sample probably comes from a depth of $12-15$ mbsf. Fortunately, a suite of dredge samples collected by R. Batiza and others in the same area of the EPR was available to supplement our limited Leg 142 data set. Most of these samples were collected from on-axis sites located directly on the crest of the EPR (Fig. 1). Several of these samples, however, were taken from dredge site 49 , an off-axis location (Batiza and Niu, 1992).

\section{Physical-properties Measurements}

Minicores were taken from the dredged basalts using 2.00- and 2.54-cm-diameter diamond coring bits. The cores were then trimmed and polished into perfect right cylinders with ends flat and parallel to within $0.008 \mathrm{~cm}$. A total of 17 minicores, including the Leg 142 samples, were obtained for physical-property analysis. Eight of these were from the off-axis dredge site.

Sample densities were determined from core weight and volume. Effective porosity was calculated from differences between the dry and saturated sample weights. The samples were then covered with copper jackets to isolate them from pressure fluid and subjected to ultrasonic velocity measurements as a function of confining pressure using a Harwood Pressure generating system and the pulse transmis- sion technique (Birch, 1960; Christensen, 1985). Shear and compressional transducers of $1 \mathrm{MHz}$ dominant frequency provided the ultrasonic sources and receivers. Velocities were measured under both dry and saturated sample conditions. Before saturated runs, samples were immersed in distilled water under a partial vacuum for 10 days. This ensured full saturation of all interconnected pore space with water.

To minimize the effects of permanent deformation caused by high confining pressures (Wissler and Simmons, 1985), each core was subject to velocity measurements in stages. First, shear- $\left(V_{s}\right)$ and compressional-wave $\left(V_{p}\right)$ velocities were measured to $50 \mathrm{MPa}$ confining pressure under dry conditions. Next, runs to $200 \mathrm{MPa}$ (equivalent to pressures at the base of normal oceanic crust) were made under both dry and saturated conditions. Lastly, measurements of $V_{p}$ and $V_{s}$ to $600 \mathrm{MPa}$ were made under saturated conditions.

\section{Scanning Electron Microscope Imaging}

To help us interpret the physical-properties measurements, in particular, to relate physical properties to the presence or absence of microcracks, we made scanning electron microscope (SEM) images of the same samples measured for velocity. Our original intent had been to prepare SEM slides from material trimmed from the minicores before the velocity measurements were made. The samples were so short, however, often only $3 \mathrm{~cm}$ long, that for reliable velocity measurement we had to keep waste to an absolute minimum. SEM slides were therefore prepared from the minicores after the velocity measurements were made. The cycling up to pressure might have introduced a small degree of cracking in the samples, but, as we shall see, many samples showed absolutely no cracking at all in the SEM images. We are confident that our inferences from the SEM images are reliable.

To prepare SEM slides, slabs cut from the minicores were impregnated with low-temperature epoxy to fill and preserve microcracks, then polished down to thin sections. The imaging itself was performed on a Cameca SX-50 electron microprobe operating in back scatter mode. Only one thin section was prepared from each of the 17 samples, but images were obtained at several locations on each section.

\section{PRELIMINARY DATA ANALYSIS}

A summary of physical-property data, including velocities, porosities, and densities, is given in Table 1 . In Figure 2, the compressional-wave velocities of the sample suite are plotted vs. shear-wave velocities under dry- and water-saturated conditions at $200 \mathrm{MPa}$. Lines of constant $V_{p} / V_{s}$ are also shown. Note that the axis samples generally fall into fields of higher $V_{p}$ and $V_{s}$ than those of the site 49 basalts. An exception to this is found in the Leg 142 cores, which display much lower velocities than their axis counterparts.

In Figure 3, compressional-wave velocities (dry) at $200 \mathrm{MPa}$ are plotted against dry bulk densities. The site 49 (i.e., off-axis) basalts fall into a distinct field of lower velocities and densities relative to the axis dredged samples. A similar pattern can be seen on a plot of sample density vs. porosity (Fig. 4), with the axis rocks displaying higher densities and slightly lower porosities than the off-axis rocks. On both plots the Leg 142 samples are distinct from the other axis samples and display extreme values. In particular, Sample 142-864B$2 \mathrm{~W}-1$, Piece 2 , has both the lowest compressional-wave velocity and the lowest density of any sample in the suite (Fig. 3).

Histograms showing $V_{p}$ and $V_{s}$ of the sample suite at $600 \mathrm{MPa}$ are presented in Figure 5. At these pressures, all low-aspect ratio pores are closed and velocities can be considered a function of sample mineralogy (Birch, 1960). The axis basalts have higher velocities in general than the off-axis basalts. Exceptions are again noted in samples 
Table 1. Summary of physical property data for the East Pacific Rise basalt suite.

\begin{tabular}{|c|c|c|c|c|c|c|c|c|c|c|c|c|c|}
\hline & \multirow{3}{*}{$\begin{array}{c}\text { Dry } \\
\text { density } \\
\left(\mathrm{g} / \mathrm{cm}^{3}\right)\end{array}$} & \multirow{3}{*}{$\begin{array}{c}\text { Wet } \\
\text { density } \\
\left(\mathrm{g} / \mathrm{cm}^{3}\right)\end{array}$} & \multirow{3}{*}{$\begin{array}{c}\text { Porosity } \\
(\%)\end{array}$} & \multicolumn{4}{|c|}{ Velocities at $50 \mathrm{MPa}(\mathrm{km} / \mathrm{s})$} & \multicolumn{4}{|c|}{ Velocities at $200 \mathrm{MPa}(\mathrm{km} / \mathrm{s})$} & \multirow{2}{*}{\multicolumn{2}{|c|}{$\begin{array}{c}\text { Vel. at } 600 \mathrm{MPa} \\
\text { Saturated }\end{array}$}} \\
\hline & & & & \multicolumn{2}{|c|}{ Dry } & \multicolumn{2}{|c|}{ Saturated } & \multicolumn{2}{|c|}{ Dry } & \multicolumn{2}{|c|}{ Saturated } & & \\
\hline & & & & $V_{p}$ & $V_{s}$ & $V_{p}$ & $V_{\text {, }}$ & $V_{p}$ & $V_{s}$ & $V_{p}$ & $V_{s}$ & $V_{p}$ & $V_{s}$ \\
\hline $\begin{array}{l}\text { On-axis samples } \\
142-864 A-5 Z-1 \text {, Piece } 3 \\
142-864 \mathrm{~B}-2 \mathrm{~W}-1 \text {, Piece } 2 \\
\text { R46-2-1 } \\
\text { R46-2-2 } \\
\text { R46-2-3 } \\
\text { R48-1-1 } \\
\text { R48-1-2 } \\
\text { R48-1-3 } \\
\text { R48-5-2 }\end{array}$ & $\begin{array}{l}2.907 \\
2.825 \\
2.906 \\
2.949 \\
2.919 \\
2.911 \\
2.893 \\
2.916 \\
2.901\end{array}$ & $\begin{array}{l}2.935 \\
2.856 \\
2.930 \\
2.963 \\
2.942 \\
2.926 \\
2.910 \\
2.927 \\
2.916\end{array}$ & $\begin{array}{l}2.80 \\
3.06 \\
2.42 \\
1.38 \\
2.23 \\
1.51 \\
1.64 \\
1.14 \\
1.47\end{array}$ & $\begin{array}{l}4.504 \\
4.307 \\
5.285 \\
5.812 \\
5.434 \\
5.392 \\
5.375 \\
5.455 \\
5.265\end{array}$ & $\begin{array}{l}2.809 \\
2.759 \\
3.189 \\
3.293 \\
3.366 \\
3.284 \\
3.240 \\
3.285 \\
3.316\end{array}$ & $\begin{array}{l}5.518 \\
5.332 \\
5.920 \\
6.047 \\
5.989 \\
6.030 \\
6.037 \\
5.924 \\
6.057\end{array}$ & $\begin{array}{l}2.974 \\
2.859 \\
3.262 \\
3.367 \\
3.367 \\
3.390 \\
3.314 \\
3.356 \\
3.363\end{array}$ & $\begin{array}{l}5.823 \\
5.485 \\
6.198 \\
6.152 \\
6.209 \\
6.287 \\
6.224 \\
6.270 \\
6.203\end{array}$ & $\begin{array}{l}3.389 \\
3.240 \\
3.515 \\
3.627 \\
3.582 \\
3.613 \\
3.575 \\
3.616 \\
3.595\end{array}$ & $\begin{array}{l}6.196 \\
5.942 \\
6.350 \\
6.149 \\
6.225 \\
6.421 \\
6.306 \\
6.507 \\
6.378\end{array}$ & $\begin{array}{l}3.444 \\
3.331 \\
3.533 \\
3.606 \\
3.611 \\
3.635 \\
3.651 \\
3.673 \\
3.642\end{array}$ & $\begin{array}{l}6.640 \\
6.404 \\
6.628 \\
6.633 \\
6.403 \\
6.674 \\
6.742 \\
6.689 \\
6.648\end{array}$ & $\begin{array}{l}3.724 \\
3.612 \\
3.670 \\
3.787 \\
3.701 \\
3.705 \\
3.693 \\
3.722 \\
3.721\end{array}$ \\
\hline Average & 2.903 & 2.923 & 1.96 & 5.203 & 3.171 & 5.873 & 3.250 & 6.095 & 3.528 & 6.275 & 3.570 & 6.607 & 3.704 \\
\hline $\begin{array}{l}\text { Off-axis samples } \\
\text { R49-4-1a } \\
\text { R49-4-1b } \\
\text { R49-4-1c } \\
\text { R49-4-1d } \\
\text { R49-4-2 } \\
\text { R49-4-3a } \\
\text { R49-4-3b } \\
\text { R49-4-4 }\end{array}$ & $\begin{array}{l}2.873 \\
2.877 \\
2.843 \\
2.862 \\
2.883 \\
2.880 \\
2.901 \\
2.846\end{array}$ & $\begin{array}{l}2.896 \\
2.900 \\
2.871 \\
2.891 \\
2.908 \\
2.902 \\
2.908 \\
2.864\end{array}$ & $\begin{array}{l}2.28 \\
2.27 \\
2.82 \\
2.96 \\
2.47 \\
2.14 \\
0.68 \\
1.78\end{array}$ & $\begin{array}{l}5.157 \\
5.223 \\
4.897 \\
4.806 \\
5.482 \\
5.308 \\
5.536 \\
4.995\end{array}$ & $\begin{array}{l}3.083 \\
3.156 \\
2.960 \\
2.939 \\
3.240 \\
3.253 \\
3.271 \\
3.033\end{array}$ & $\begin{array}{l}5.659 \\
5.608 \\
5.524 \\
5.563 \\
5.796 \\
5.749 \\
5.908 \\
5.574\end{array}$ & $\begin{array}{l}3.051 \\
3.085 \\
2.943 \\
3.007 \\
3.268 \\
3.055 \\
3.258 \\
2.994\end{array}$ & $\begin{array}{l}5.780 \\
5.812 \\
5.790 \\
5.877 \\
6.011 \\
6.004 \\
5.924 \\
5.993\end{array}$ & $\begin{array}{l}3.325 \\
3.365 \\
3.322 \\
3.356 \\
3.438 \\
3.360 \\
3.394 \\
3.429\end{array}$ & $\begin{array}{l}6.074 \\
6.025 \\
6.041 \\
6.101 \\
6.184 \\
6.250 \\
6.149 \\
6.155\end{array}$ & $\begin{array}{l}3.349 \\
3.347 \\
3.323 \\
3.384 \\
3.476 \\
3.330 \\
3.425 \\
3.381\end{array}$ & $\begin{array}{l}6.463 \\
6.495 \\
6.442 \\
6.503 \\
6.528 \\
6.596 \\
6.444 \\
6.524\end{array}$ & $\begin{array}{l}3.607 \\
3.630 \\
3.608 \\
3.636 \\
3.618 \\
3.626 \\
3.591 \\
3.676\end{array}$ \\
\hline Average & 2.871 & 2.893 & 2.18 & 5.176 & 3.117 & 5.673 & 3.083 & 5.899 & 3.374 & 6.122 & 3.377 & 6.499 & 3.624 \\
\hline
\end{tabular}

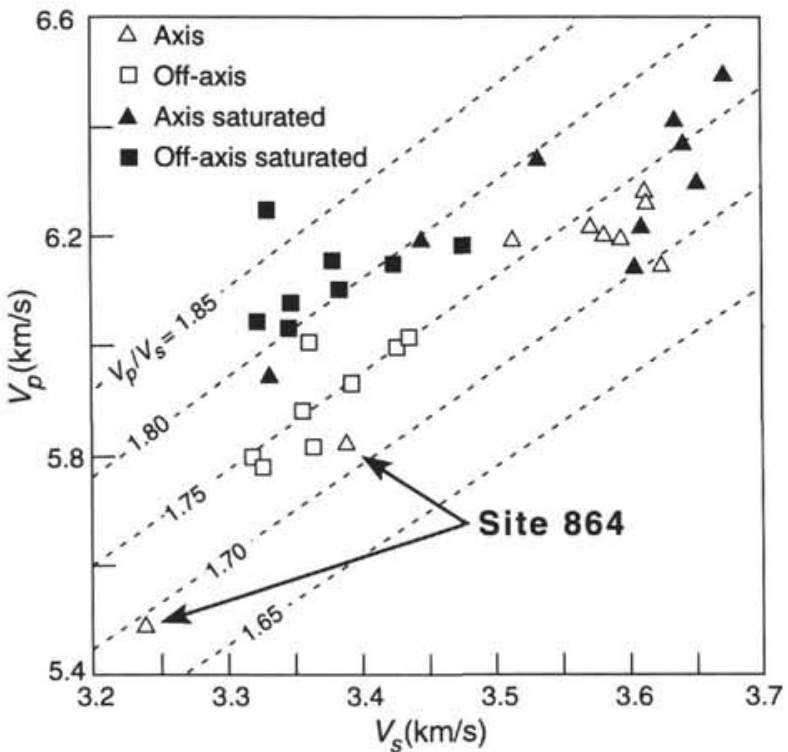

Figure 2. Compressional-wave velocities of the sample suite plotted against shear velocities under both saturated and unsaturated conditions at $200 \mathrm{MPa}$. Lines of constant $V_{p} / V_{s}$ are also shown.

R46-2-3, which has a relatively low $V_{p}$, and 142-864B-2W-1, Piece 2, which displays relatively low $V_{p}$ and $V_{s}$.

The velocity and density data presented in figures $2,3,4$, and 5 show that the on-axis and off-axis dredge basalts are distinctly different. Petrographic examinations of thin sections cut from core ends generally show larger grain sizes, lower glass contents, and greater vesicularities for the off-axis basalt samples. We find no petrographic evidence for weathering in the dredge samples, nor do grain density measurements indicate any alteration (from wet-bulk density measurements we find that grain densities for all samples fall between 2.9 and 3.0). The Leg 142 basalts do not follow the physical-property trends of either the axis or off-axis dredge samples. The anomalous behavior of these basalts can be attributed to their porosity structures and will be discussed in greater detail below.

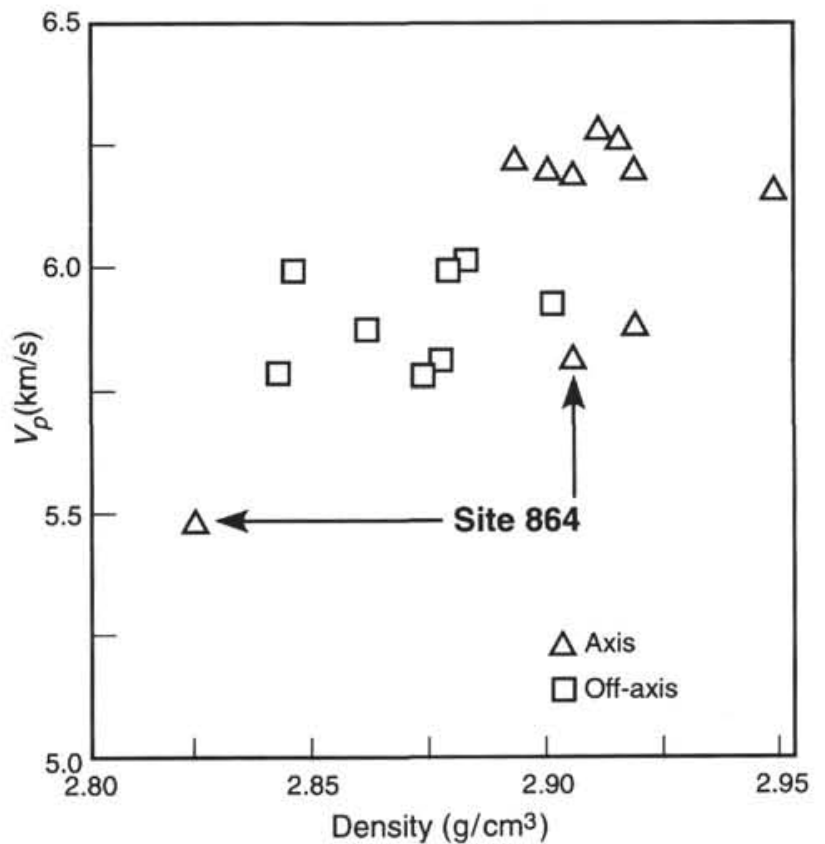

Figure 3. Compressional-wave velocity, measured at $200 \mathrm{MPa}$, vs. dry bulk density for East Pacific Rise basalts.

\section{VELOCITY-POROSITY RELATIONSHIPS}

A wide variety of rock physics theories relate the elastic moduli of a porous rock to the porosity structure (Walsh, 1965; Kuster and Toksöz, 1974; O'Connell and Budiansky, 1974; Cheng and Toksöz, 1979). The moduli depend not only on the overall concentration of void space (i.e., the porosity) but also on void shape. The simplest measure of shape is aspect ratio, the ratio of the width of a void to its length. One of the most basic and consistent predictions of all theories is that for a given porosity, low-aspect ratio voids (such as microcracks) have a much greater effect on elastic moduli, and hence seismic velocities, than high-aspect ratio voids (such as vesicles) 


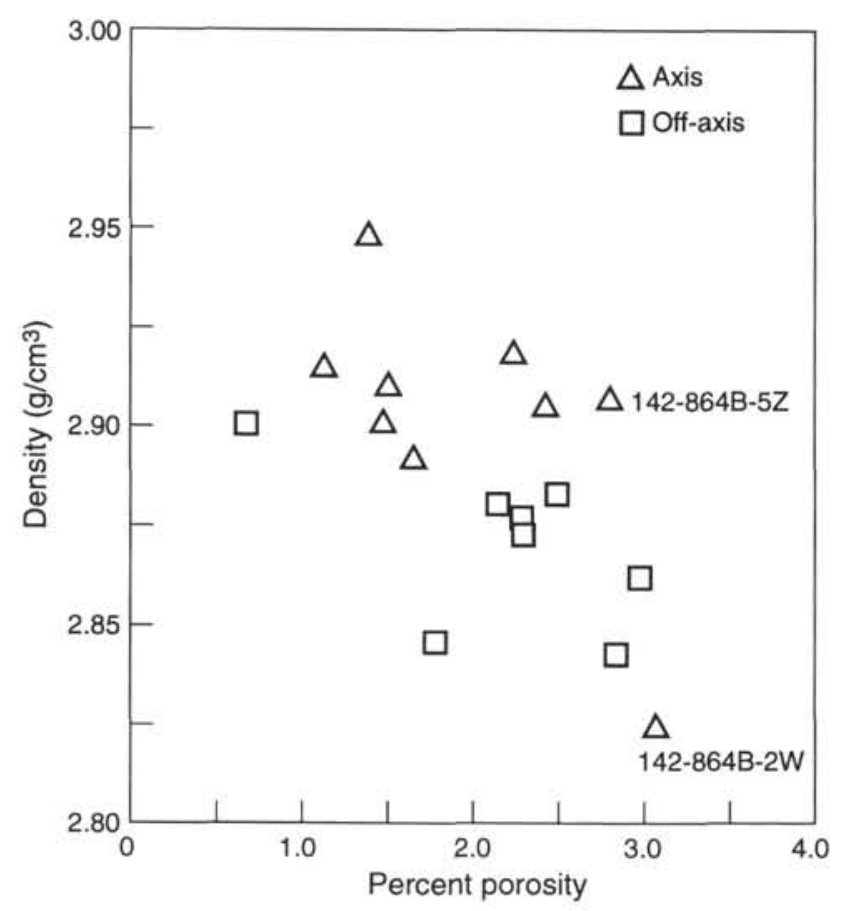

Figure 4. Sample density vs. porosity for East Pacific Rise basalts.

(Toksöz et al., 1976). Experiment confirms the theory: at low confining pressures, very small concentrations of low-aspect ratio cracks greatly reduce seismic velocities relative to velocities at high pressures when the cracks are closed. Further, at low confining pressure, the saturation of a rock containing dominantly low aspect ratio pores results in a large increase in compressional-wave velocity (Nur and Simmons, 1969). Much smaller increases in $V_{p}$ after saturation can be expected in rocks containing an equal volume of high-aspect-ratio pores (Toksöz et al., 1976).

In Figure 6, the difference between the saturated and unsaturated compressional-wave velocity $\left(\Delta V_{p}\right)$ of the EPR basalts is plotted as a function of confining pressure. As might be expected, $\Delta V_{p}$ increased for each sample due to closure of microcracks as confining pressure was increased to $200 \mathrm{MPa}$. The Leg 142 samples displayed the highest values of $\Delta V_{p}$ at each pressure point, indicating that these rocks contain a greater concentration of microcracks than the dredged basalts. The on-axis and off-axis dredge basalts showed no significant differences in behavior relative to each other. Shear-wave velocities were found to be relatively insensitive to saturation conditions for all of the basalts, consistent with the findings of Nur and Simmons (1969). Shear-wave velocities either increased or decreased upon saturation, with typical $\Delta V_{p}$ of $0.2 \mathrm{~km} / \mathrm{s}$ or less at $10 \mathrm{Mpa}$, decreasing with increasing confining pressure.

The rock physics theory of perhaps the broadest application is that developed by Kuster and Toksöz (1974). The Kuster-Toksöz theory is valid for all aspect ratios, from perfect spheres (aspect ratio unity) to thin microcracks (aspect ratio $<0.0001$ ). The theory is "noninteractive" in that each crack is treated as if it exists in an uncracked matrix. The noninteraction restricts the theory to low overall porosity (Kuster and Toksöz, 1974; Toksöz et al., 1976), but iterative extensions of the theory mean that the low-porosity restriction can be relaxed (Cheng, 1978; Berge et al., 1992). Cheng and Toksöz (1979) were able to devise an inversion of the Kuster-Toksöz theory. From measurements of seismic velocity at different pressures, the Cheng-Toksöz scheme estimates the aspect ratio spectrum (i.e., the distribution of porosity over aspect ratio). The inversion has been used to estimate the porosity structure of sandstones (Burns et al.,
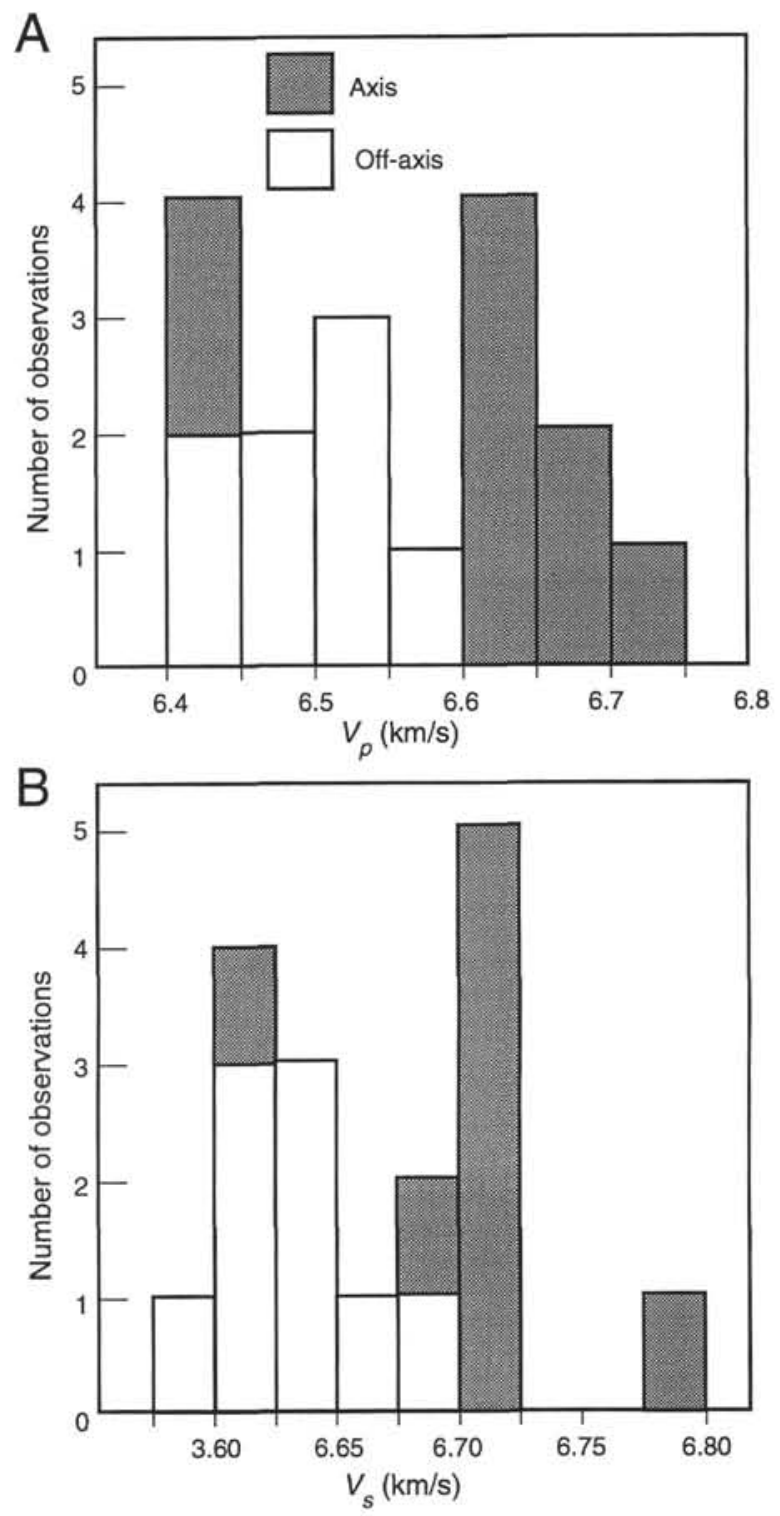

Figure 5. Compressional-wave (A) and shear-wave (B) velocities of the sample suite at $600 \mathrm{MPa}$.

1990) and basalts (Kowallis et al., 1982), but has not previously been used on seafloor rocks.

The Cheng-Toksöz scheme is a standard nonlinear inversion: an initial guess of the aspect ratio spectrum is iteratively improved by minimizing the difference between velocities measured and velocities predicted by the theory (Cheng and Toksöz, 1979). In addition to measurements of $V_{p}$ and $V_{s}$ as functions of confining pressure, the scheme requires bulk and shear moduli of the matrix material, the moduli of pore-filling material, and the total porosity of the rock. The user must specify which aspect ratios are to be considered.

We chose to use the Cheng-Toksöz scheme to invert our "dry" (air saturated) velocity runs to $200 \mathrm{MPa}$ to obtain the pore aspect ratio spectra of the basalts. The aspect ratios solved for in all inversions are listed in Table 2. There are several reasons for choosing this set of aspect ratios. It is not realistic to suggest that the exact pore aspect ratios of a rock sample can be specified given the complex porosity structures of rocks as observed during SEM studies (Burns et al., 1990). Thus the constant range of pore aspect ratios shown in Table 
2 was used during all inversions, forcing the program to apportion total porosity among them. The smallest aspect ratio, 0.0005 , was chosen because preliminary modeling showed that thinner cracks were unrealistic. Aspect ratios from approximately 0.0005 to 0.005 generally close over the pressure range of interest and are thus well resolved by the program. Pores of higher aspect ratio $(0.1$ and 1.0$)$ have minor effects on velocity and act merely as "dumps" so that calculated porosities equal the total true porosity. These considerations resulted in the pore aspect ratios listed in Table 2.

Seven basalts (usually the longer samples) displayed velocity data of adequate resolution to be used in the inversion runs. For each of these basalt cores we obtained sharp compressional- and shear-wave arrivals uncontaminated by transducer noise. Four of these were axis samples (including the two Leg 142 samples); three were from site 49. The matrix moduli of the basalts were approximated using their $600-\mathrm{MPa}$ velocity data extrapolated to $1000 \mathrm{MPa}$. The elastic moduli of the pore-filling material (air) was taken from Toksöz et al. (1976). Results of a typical inversion run are shown in Figure 7. Overall, the fit of the calculated to the observed velocities for Sample 142-864B-

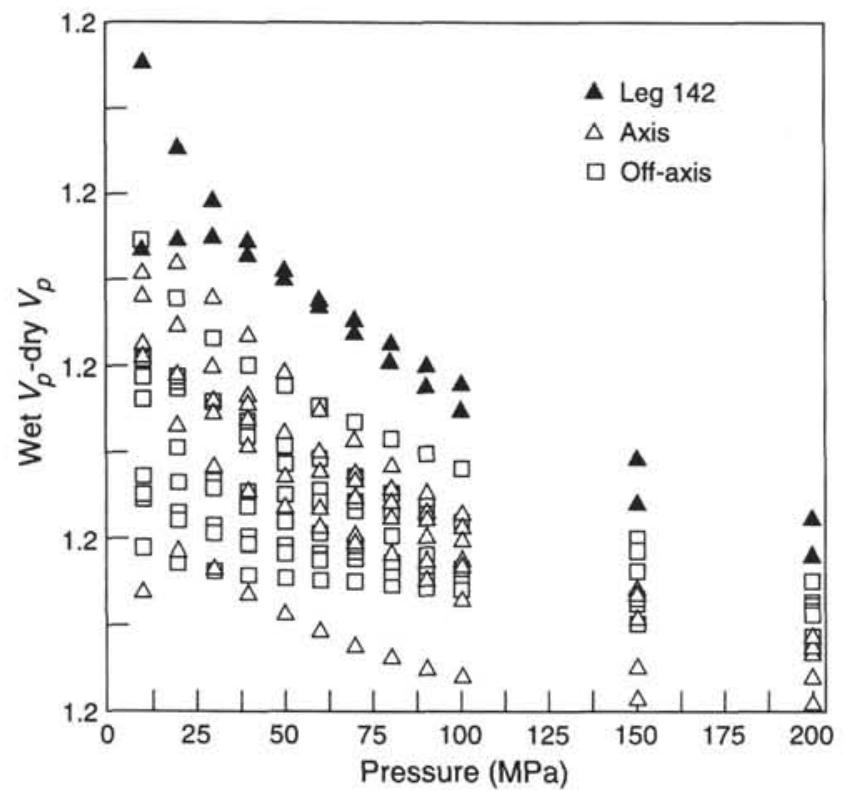

Figure 6. Difference between water-saturated and dry compressional-wave velocities of East Pacific Rise basalts as a function of confining pressure.
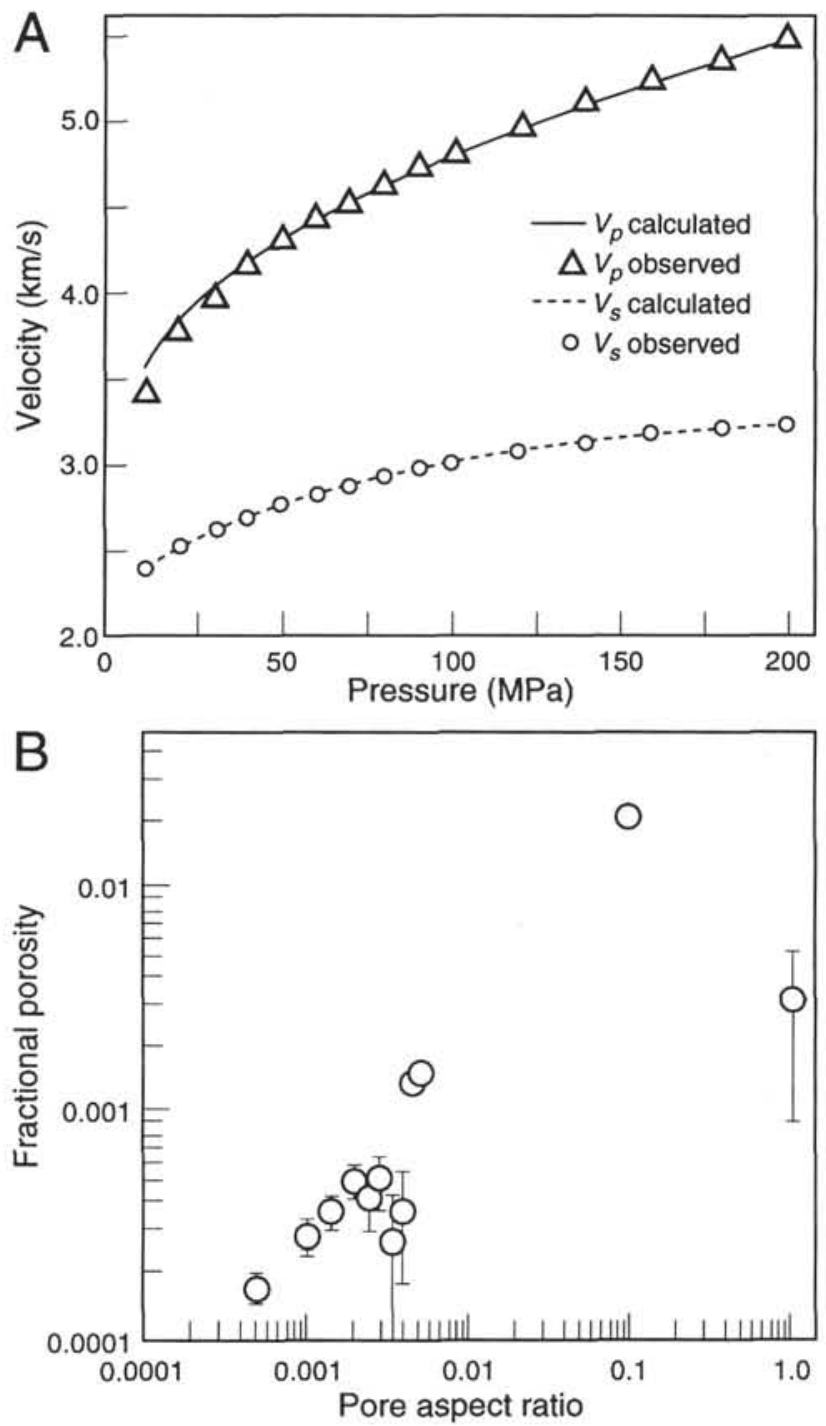

Figure 7. Results of inversion runs for Sample 142-864B-2W-1, Piece 2. A. Observed and calculated velocities as functions of confining pressure. B. Pore aspect ratio spectrum showing fractional porosities assigned to each aspect ratio.

Table 2. Porosity distribution over aspect ratio from inversion of velocities.

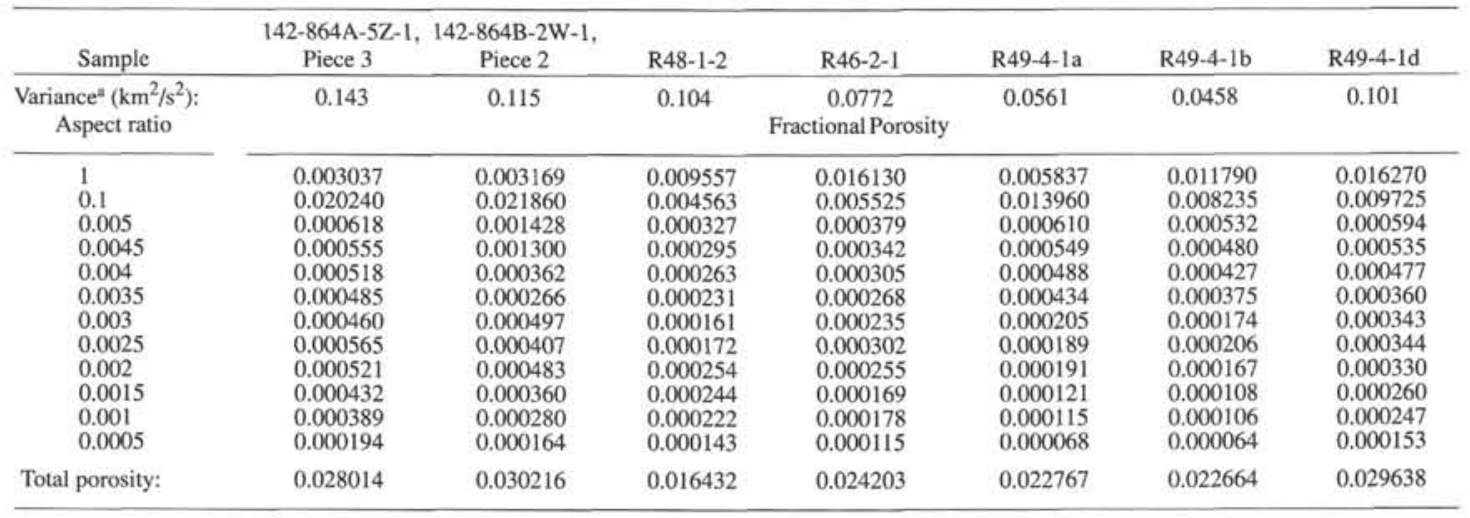

"Variance between measured and predicted compressional and shear velocities. 
$2 \mathrm{~W}-1$, Piece 2, is good, with only slight differences in $V_{p}$ observed at low pressures. Also shown are the fractional porosities attributed to each aspect ratio by the Cheng-Toksöz code (the fractional porosities sum to the measured porosity, a constraint in the inversion). Error bars represent one standard deviation and give an indication of how input data errors would influence the output spectra.

Extensive testing reveals that the models produced by the inversions are unique because slight variations in input matrix moduli and input pore aspect ratios do not change the overall characteristics of the pore aspect ratio spectra for a given rock (Burns et al., 1990). In general, the fractional porosities we find for pores of aspect ratio $0.0005-0.004$ are well resolved, those for aspect ratios 0.0045 and 0.005 are moderately well resolved, and fractional porosities for pores of aspect ratios 0.1 and 1.0 are poorly resolved. The pore aspect ratio spectra obtained from the inversions, together with the variances in the fit between observed and predicted velocities, are shown in Table 2. The results are displayed graphically in Figure 8 . The Hole $864 \mathrm{~A}$ and $864 \mathrm{~B}$ samples contain a significantly greater amount of porosity in aspect ratios $0.0005-0.003$ than the other basalts. Samples R49-4-1a and R49-4-1b contain a very small amount of porosity in these aspect ratios whereas R49-4-1d, R48-1-2, and R46-2-1 contain intermediate amounts. In aspect ratios $0.0035-0.005$, it appears that the off-axis samples and the Leg 142 basalts contain a greater amount of porosity than do R48-1-2 and R46-2-1. The extremely high porosities in aspect ratios 0.0045 and 0.005 displayed by the Hole $864 \mathrm{~B}$ sample may be the result of poor resolution.

In Figure 9A, the differences between the water-saturated and dry compressional-wave velocities of the seven basalts at $50 \mathrm{MPa}$ are plotted against their fractional porosities in pores of aspect ratio 0.0005 . A good correlation exists between these quantities, with the samples containing large fractional porosities also displaying large differences in $V_{p}$. These results agree with the findings of Nur and Simmons (1969) and Toksöz et al. (1976), who found that saturation of low-aspect ratio pores, or microcracks, causes a large increase in compressional-wave velocities at low confining pressures. Figure $9 \mathrm{~A}$ also lends support to the pore aspect ratio spectra models, because the water-saturated data were not used in the inversions. In Figure $9 \mathrm{~B}$ a similar plot is shown, this time using shear-wave velocities. The trend of points indicates that water-saturated $V_{s}$ increases slightly relative to dry $V_{s}$ as low aspect ratio porosity is increased. Note the rel-

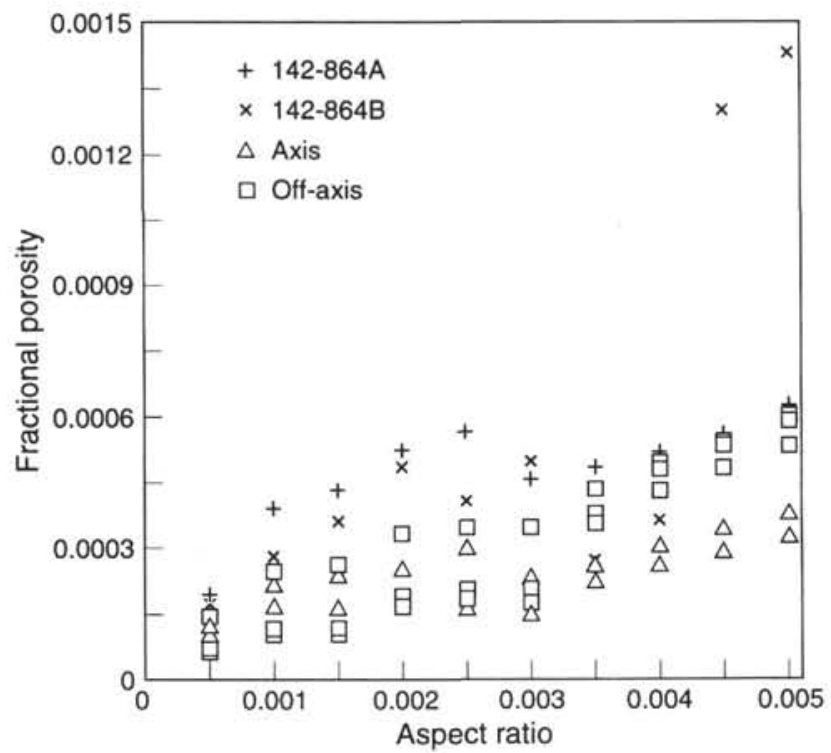

Figure 8. Summary of pore aspect ratio spectra produced from inversions. ative insensitivity of $V_{s}$ to saturation conditions (Fig. 9B) compared to the much greater sensitivity of $V_{p}$ (Fig. 9A).

\section{SEM IMAGES}

We performed very minor image processing of the SEM images to improve the visibility of microcracks. Standard procedures like edge detection and emphasis filtering could not differentiate between cracks and crystal edges or between cracks and thin crystals with thicknesses close to the image resolution. We therefore chose instead simply to adjust intensity levels to maximize the contrast between the cracks and the surrounding material. This produced images in which open cracks are black and the rest of the image white or gray (Pl. 1).

Both Site 864 samples show a high degree of cracking, as can be seen in Plate 1, Figures 1 and 2. Rocks dredged from the EPR axis, however, show many fewer cracks than the drilled rocks (Pl. 1, Fig.
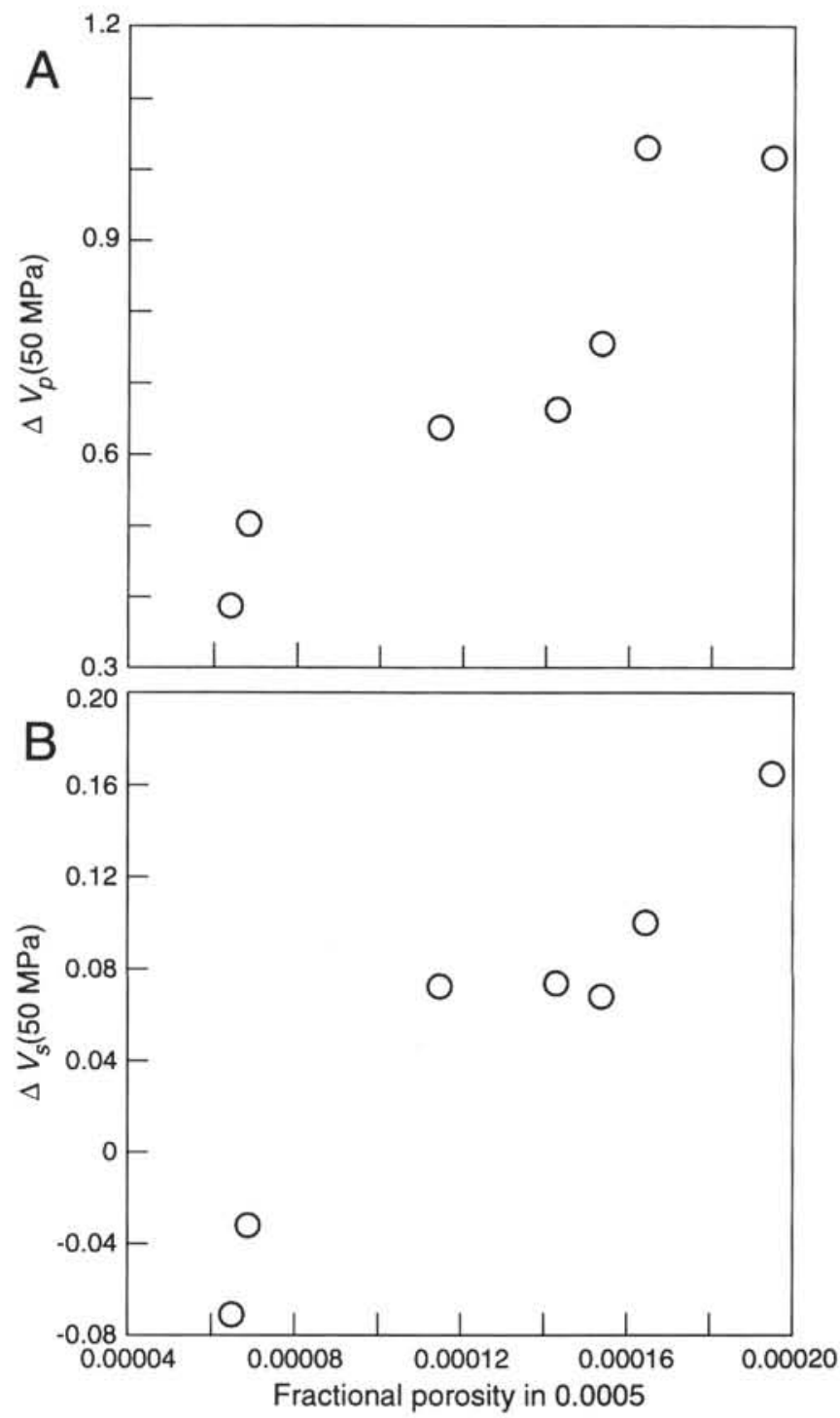

Figure 9. Difference between wet and dry velocities of seven samples, measured at $50 \mathrm{MPa}$, plotted against their fractional porosities in pores of aspect ratio 0.0005 . A. Compressional-wave velocities. B. Shear-wave velocities. 
3). Rocks from the flanks show both behaviors, with some rocks almost free of cracks (Pl. 1, Fig. 4) and some with almost as many cracks as the drill samples ( $\mathrm{Pl}$. 1, Fig. 5). These observations generally agree with the inversions of the velocity data: the rocks for which the velocity inversions indicate a high population of thin cracks are the same rocks which qualitatively display the highest crack density on the SEM images.

The comparison between SEM images and velocity inversions should strictly be limited to intermediate aspect ratios. Velocity inversion is most robust for aspect ratios less than 0.005 , but SEM resolution is best for aspect ratios greater than about 0.005 (Kowallis et al., 1982). If we scrutinize the fractional porosities for aspect ratios from 0.005 to 0.003 in Table 2, we find that the highest porosities are for the Leg 142 samples, the rocks dredged from the axis (R48-1-2 and R46-2-1) have the lowest porosities, and the rocks dredged from the flanks (R49-4-1a-d) have intermediate values. The only exception to this rule is the low porosity at aspect ratio 0.0035 for Sample 142-864B-2W-1, Piece 2 . The overall porosity structure determined by the velocity inversions is in perfect agreement with what we see in the SEM images.

\section{DISCUSSION: THE ORIGIN OF THE CRACKS}

The two samples from Site 864 are the clear anomalies in this suite of rocks. They show significantly lower seismic velocities than the dredged rocks from the EPR axis and their SEM images show a much higher degree of cracking. The Site 864 basalts more closely match the off-axis rocks, both in seismic velocities and in crack density apparent from SEM images, but the match is not perfect. The Site 864 rocks have lower velocities and, from the inversions, higher crack concentration near aspect ratio 0.005 .

The dredge rocks from the axial summit graben are fragments from lobate flows and massive ponded lavas, but the off-axis rocks are predominantly from pillows (Batiza and Niu, 1992; R. Batiza, pers. comm., 1993). The different lava morphologies may explain the different physical properties on and off axis; in ophiolites, pillows have a higher proportion of cracks and therefore lower seismic velocities than sheet flows (Ludwig et al., 1993). Holes 864 and 864B, however, are inferred to be through massive, lobate, and sheet flows (Shipboard Scientific Party, 1993), so the Site 864 basalts should match the axial dredge samples and show fewer cracks and higher velocities. Some explanation is therefore necessary for the high crack concentrations and low velocities of the basalts recovered by drilling.

It is tempting to invoke abuse suffered in the drilling process as the explanation for the large crack concentrations. That explanation does not really fit. It is true that poor control of weight-on-bit when using the diamond coring system (DCS) meant that rocks were subjected quite literally to a hammering by the drill bit (Storms, 1993), but that applies only to Hole 864A. The Hole 864B core was not collected with the DCS but with a diamond core barrel on the standard drill string (Storms, 1993). Although no diamond-trimmed "core" was ever recovered from Hole 864A, the single Hole 864B core was indeed diamond trimmed (Storms, 1993) and clearly had not suffered the same degree of damage as the Hole $864 \mathrm{~A}$ rocks. Yet our velocity measurements for Holes 864A and 864B are similar, and the rocks have comparable crack concentrations. Some explanation other than drilling abuse has to be found.

The answer appears to be related to grain size. The rocks of this suite vary from fine-grained to cryptocrystalline with the lowest velocities systematically being measured in the rocks with largest crystals. All of the axis dredge rocks are sparsely phyric with plagioclase microphenocrysts in a cryptocrystalline groundmass. When dry, all of these rocks have a compressional velocity in excess of $5 \mathrm{~km} / \mathrm{s}$ at $50 \mathrm{MPa}$ (Table 1) and all display a low level of cracking in the SEM imaging (Pl. 1, Fig. 3). The off-axis rocks are generally fine grained, with the proportion of phenocrysts being greatest in R49-4-1c, R49-4-1d, and R49-4-4. These three rocks show the lowest velocities (Table 1) and the highest crack concentrations (Table 2 and PI. 1, Figs. 4 and 5). The Site 864 rocks are also fine grained and also show low velocities (Table 1) and large crack concentrations (Table 2 and Pl. 1, Figs. 1 and 2). For the fine-grained rocks, the SEM imaging shows that cracks are concentrated in the plagioclase phenocrysts and the larger crystals of the groundmass (Pl. 1).

We find exceptionally few filled cracks (one appears in Pl. 1, Fig. 2 ), which leads us to believe that many of the cracks were not present in the rocks at the seafloor. The cracks may have been introduced by the reduction of confining pressure by approximately $30 \mathrm{MPa}$ that resulted from bringing up the rocks from the seafloor. What void space existed in the rocks on the seafloor would have been seawater saturated, but with a low population of microcracks the rocks would have too low a permeability for that trapped water to lose pressure. Bringing the rocks to the surface would result in a pore pressure approaching $30 \mathrm{MPa}$ in excess of confining pressure, which is quite adequate to crack the rock. That overpressured water in pore space has resulted in cracking is apparent from Plate 1, Figure 1, where a near-spherical pore (right) has been the nucleation point for radiating microcracks.

If the cracks result from a reduction in confining pressure, why should only the larger crystals be cracked? A rock with microcrystalline or cryptocrystalline texture has much more homogeneous elastic properties than a fine-grained rock with its much coarser texture. With homogeneous elastic properties there is less opportunity for the excess pore pressure to result in the stress concentrations necessary to crack the rock, and once a crack does start propagating there are more grain boundaries to arrest its advance (each of the images of Plate 1 has some cracks truncated against grain boundaries).

The microcracks are definitely not a consequence of running the samples up to $600 \mathrm{MPa}$ to measure seismic velocities. With an increase in pressure cracks close rather than open, and no sample showed much hysteresis (the difference in seismic velocities measured while increasing and while decreasing pressure). The cracks had to be present before the velocity measurements were taken.

\section{CONCLUSIONS}

Rocks from Site 864 have substantially lower seismic velocities than rocks dredged from the axis of the East Pacific Rise near the drill site at $9^{\circ} 31^{\prime} \mathrm{N}$, but have properties very similar to rocks from an off-axis dredge site. Inversion of velocity measurements made at different pressures shows that the velocity difference between the Site 864 rocks and the axis dredge rocks results from a higher population of thin cracks in the drilled rocks, a result which we have qualitatively verified from SEM images. We do not think that the higher degree of cracking of the drilled rocks is damage suffered during drilling; instead we believe that it is the consequence of overpressuring of pore space as the rocks were raised from the seafloor. If pressure release is indeed the cause of the cracks then laboratory measurements of seismic velocities in very young seafloor rocks must be interpreted with caution.

\section{ACKNOWLEDGMENTS}

We thank Arthur Cheng for use of his velocity inversion program, Jill Karsten for advice in running the microprobe, and Steve Martell for stimulating discussions on the physical properties of cracked rocks. Matt Salisbury and Bill Wepfer provided helpful reviews. This work was supported by JOI-USSAC grants and by Office of Naval Research grant N00014-90-J-1625. SOEST contribution number 3529 . 


\section{REFERENCES}

Batiza, R., and Niu, Y., 1992. Petrology and magma chamber processes at the East Pacific Rise $\approx 9^{\circ} 30$ N. J. Geophys. Res., 97:6779-6797.

Berge, P.A., Fryer, G.J., and Wilkens, R.H., 1992. Velocity-porosity relationships in the upper oceanic crust: theoretical considerations. J. Geophys. Res., 97:15239-15254.

Birch, F., 1960. The velocity of compressional waves in rocks to 10 kilobars, Part 1.J. Geophys. Res., 65:1083-1102.

Burns, D.R., Cheng, C.H., and Wilkens, R.H., 1990. Sandstone pore aspect ratio spectra from direct observations and velocity inversion. Int. J. Rock Mech. Min. Sci. Geomech. Abstr., 27:315-323.

Cheng, C.H., 1978. Seismic velocities in porous rocks: direct and inverse problems [Ph.D. dissert.]. Mass. Inst. Tech., Cambridge, MA.

Cheng, C.H., and Toksöz, M.N., 1979. Inversion of seismic velocities for the pore aspect ratio spectrum of a rock. J. Geophys. Res., 84:7533-7543.

Christensen, N.I., 1985. Measurements of dynamic properties of rocks at elevated temperatures and pressures. In Pincus, H.J., and Hoskins, E.R. (Eds.), Measurement of Rock Properties at Elevated Pressures and Temperatures: Philadelphia (Am. Soc. for Testing and Materials), ASTM STP 869:93-107.

Christeson, G.L., Purdy, G.M., and Fryer, G.J., 1992. Structure of young upper crust at the East Pacific Rise near $9^{\circ} 30^{\prime}$ N. Geophys. Res. Lett., 19:1045-1048.

Harding, A.J., Orcutt, J.A., Kappus, M.E., Vera, E.E., Mutter, J.C., Buhl, P., Detrick, R.S., and Brocher, T.M., 1989. The structure of young oceanic crust at $13^{\circ} \mathrm{N}$ on the East Pacific Rise from expanding spread profiles. $J$. Geophys. Res., 94:12163-12196.

Houtz, R., and Ewing, J., 1976. Upper crustal structure as a function of plate age. J. Geophys, Res., 81:2490-2498.

Jacobson, R.S., 1992. Impact of crustal evolution on changes of the seismic properties of the uppermost ocean crust. Rev. Geophys., 30:23-42.

Kowallis, B.J., Roeloffs, E.A., and Wang, H.F., 1982. Microcrack studies of basalts from the Iceland Research Drilling Project. J. Geophys. Res., 81:2490-2498.

Kuster, G.T., and Toksöz, M.N., 1974. Velocity and attenuation of seismic waves in two-phase media: Part I-theoretical formulations. Geophysics. 39:587-606.

Ludwig, N.A., Karsten, J.L., Wilkens, R.H., and Fryer, G.J., 1993. Geometry and orientation of pore space in oceanic crust: constraints from the Troodos Ophiolite. Eos, 74:559.

Nur, A., and Simmons, G., 1969. The effect of saturation on velocity in low porosity rocks. Earth Planet. Sci. Lett., 7:183-193.

O'Connell, R.J., and Budianski, B., 1974. Seismic velocities in dry and saturated cracked solids. J. Geophys. Res., 79:5412-5426.

Purdy, G.M., 1987. New observations of the shallow seismic structure of young oceanic crust. J. Geophys. Res., 92:9351-9362.
Purdy, G.M., and Ewing, J.I., 1986. Seismic structure of oceanic crust. In Tulcholke, B.E., and Vogt, P.R. (Eds.), The Western Atlantic Region. Geol. Soc. Am., Geol. of North Am. Ser., M:313-331.

Schreiber, E., and Fox, P.J., 1976. Compressional wave velocities and mineralogy of fresh basalts from the FAMOUS area and the texture of Layer 2A in the oceanic crust. J. Geophys. Res., 85:1409-1433.

Shipboard Scientific Party, 1993. Site 864. In Storms, M.A., Batiza, R., et al., Proc. ODP, Init. Repts., 142: College Station, TX (Ocean Drilling Program), 55-72.

Spudich, P., and Orcutt, J., 1980. Petrology and porosity of an oceanic crustal site: results from wave form modeling of seismic refraction data. J. Geophys. Res., 85:1409-1433.

Storms, M.A., 1993. Operations report. In Storms, M.A., Batiza, R., et al., Proc.ODP, Init. Repts., 142: College Station, TX (Ocean Drilling Program), 5-27.

Toksöz, M.N., Cheng, C.H., and Timur, A., 1976. Velocities of seismic waves in porous rocks. Geophysics, 41:621-645.

Vera, E.E., Mutter, J.C., Buhl, P., Orcutt, J.A., Harding, A.J., Kappus, M.E., Detrick, R.S., and Brocher, T.M., 1990. The structure of 0- to 0.2 m.y.-old oceanic crust at $9^{\circ} \mathrm{N}$ on the East Pacific Rise from expanded spread profiles. J. Geophys. Res., 95:15529-15556.

Walsh, J.B., 1965. The effect of cracks on the compressibility of rock. $J$. Geophys. Res., 70:381-389.

Wilkens, R., Schultz, D., and Carlson, R., 1988. Relationship of resistivity, velocity, and porosity for basalts from downhole well-logging measurements in Hole 418A. In Salisbury, M.H., Scott, J.H., et al., Proc. ODP, Sci. Results, 102: College Station, TX (Ocean Drilling Program), 69-75.

Wilkens, R.H., Fryer, G.J., and Karsten, J., 1991. Evolution of porosity and seismic structure of upper oceanic crust: importance of aspect ratios. $J$. Geophys. Res., 96:17981-17995.

Wissler, T.M., and Simmons, G., 1985. The physical properties of a set of sandstones, Part II. Permanent and elastic strains during hydrostatic compression to $200 \mathrm{MPa}$. Int. J. Rock Mech. Min. Sci. Geomech. Abstr., 22:393-406.

\section{Date of initial receipt: 8 October 1993 \\ Date of acceptance: 6 May 1994 \\ Ms 142SR-106}

\footnotetext{
Abbreviations for names of organizations and publications in ODP reference lists follow the style given in Chemical Abstracts Service Source Index (published by American Chemical Society).
} 

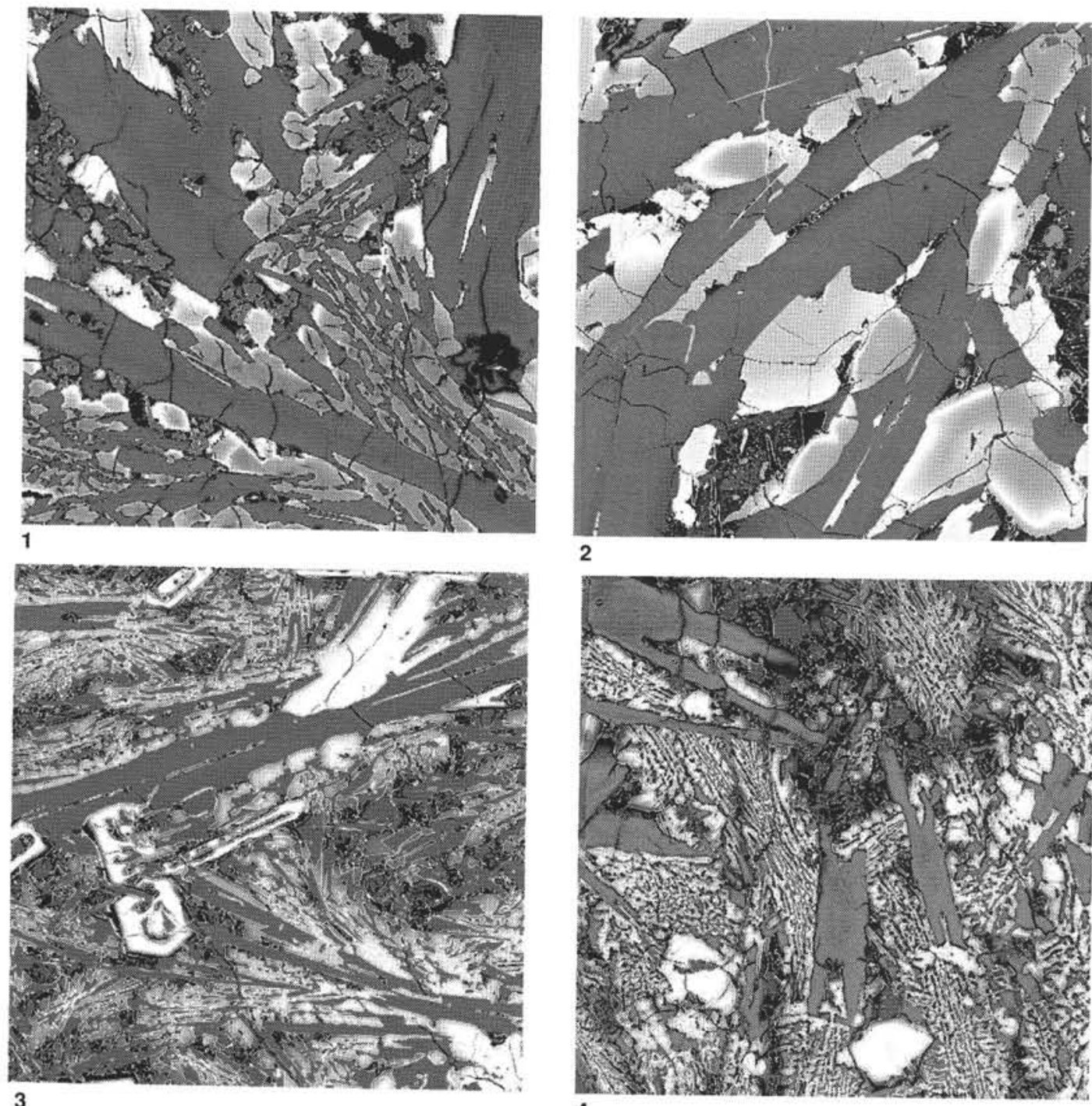

2
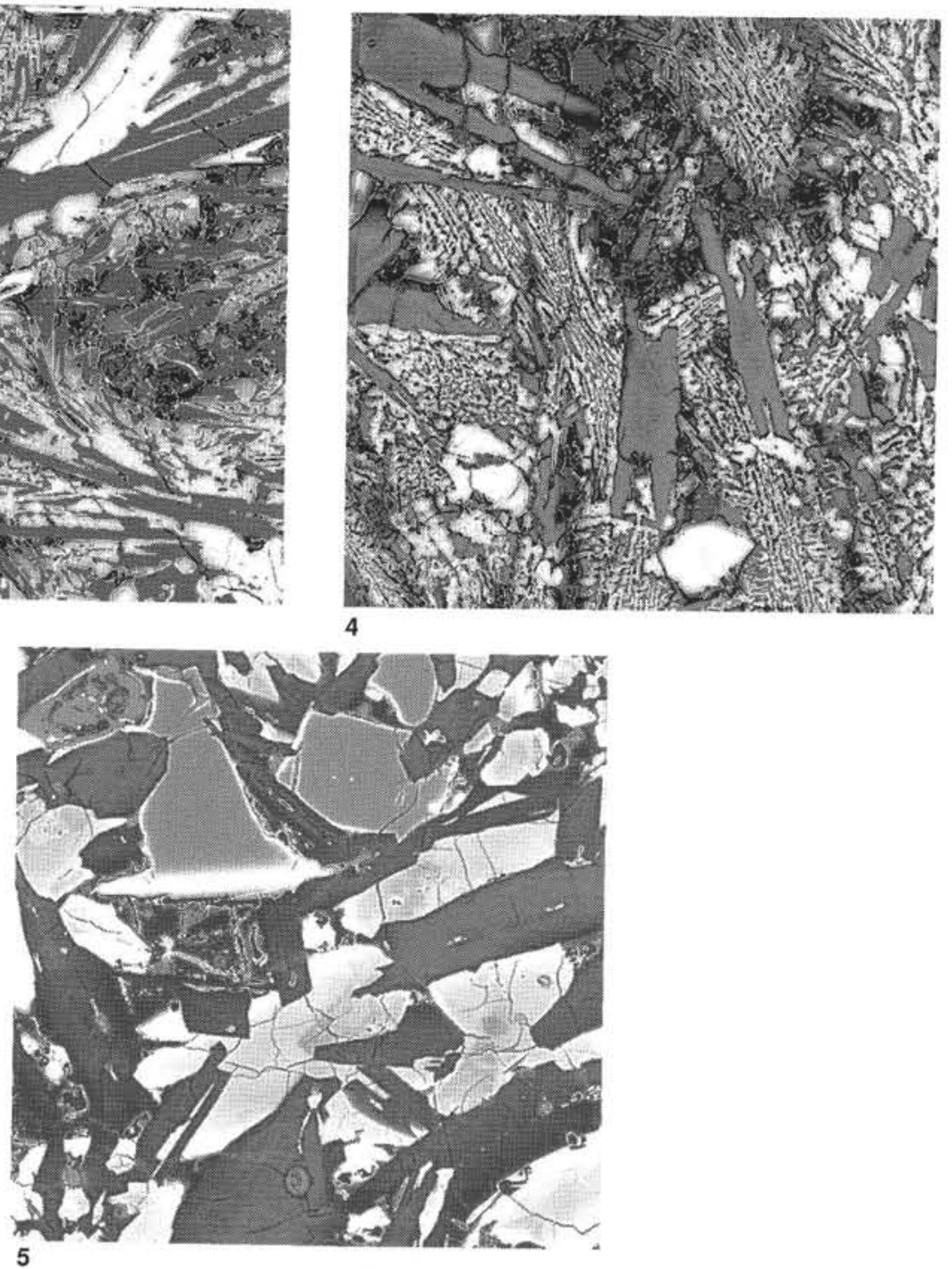

Plate 1. Scanning electron microscope images. The field of view of each image is $0.19 \mathrm{~mm}$ across except for Figure 2, which is $0.37 \mathrm{~mm}$ across. Images have been adjusted so that microcracks and vesicles are black. 1. Sample 142-864A-5Z-1, Piece 3. Note the open pore (black, right edge) which has acted as a nuclePacific Rise axicrocracks. 2. Sample 142-864B-2W-1, Piece 2. Note the filled crack (white, top, left of center). 3. Dredged Sample R46-2-1, from the East Pacific Rise axis. 4. Off-axis dredged Sample R49-4-2. 5. Off-axis dredged Sample R49-4-1a. 